\title{
The predicting abilities of social trust and good governance on economic crisis duration
}

\author{
Jessica Nguyen \\ Norwegian School of Economics \\ Tue Dinh \\ Norwegian School of Economics \\ Marcus Selart \\ Norwegian School of Economics
}

Norwegian School of Economics Reports 


\begin{abstract}
In this paper, we uncover the relationships among social trust, corruption and the duration of economic crises. Our theoretical foundation is based on a collection of studies from different academic fields, especially political science, sociology and economics. We corroborate our arguments with both descriptive analysis and regression analysis of secondary data. Our dataset includes 11,364 observations distributed across 211 countries. The quantitative findings show that social trust is correlated with the duration of economic crises. Connecting our theoretical stance with the empirical evidence, we propose several possible explanations for the findings and provide both theoretical and practical implications.
\end{abstract}

Keywords: trust; corruption; economic crisis, public policy; social justice 


\section{Introduction}

From time to time, the media asserts that corruption hinders economic growth and keeps corrupt nations from advancing further on their economic journey. There is no doubt that corruption plays a key role in the development level of a country. No country is free of corruption or the responsibility for finding international solutions to it, though the problem is generally more widespread in low-income than wealthier countries (Søreide, 2016). What factors determine the wealth of a nation? A general consensus is that technology, natural resources and physical and human capital constitute such factors (Jorgenson, 1991). However, from a social capital theorist perspective, the positive and negative social forces within each society can either harm or strengthen the affluence of a nation (Ostrom \& Ahn, 2009). From this standpoint, a less familiar factor emerges and plays a key role in assessing the level of wealth-namely, social trust. Prior research reveals that there is a strong relationship between corruption and social trust (Rothstein, 2005).

Several links may connect economic crisis with corruption and social trust. Corruption and social trust are closely linked through mutual connections with inequality. This is because a dishonest government results in higher inequality and lower social trust (Rothstein, 2005). In addition, several studies have examined the relationship between crime and employment, earnings or labour market conditions (see Fougère et al., 2010; Lin, 2008; Raphael \& Winter-Ebmer, 2001). Despite evidence that economic crisis and crimes are potentially related, few studies have focused on the relationship between economic crisis and corruption. Therefore, the purpose of this study is to investigate the connections among economic crisis, social trust and corruption in society. 
First, we present our theoretical framework along with the hypotheses. In this part, we conduct a literature review of what has been done, examining the most recent studies on social trust, economic crisis and corruption. Second, we present our methodology and empirical approach. In this part, we begin with a presentation of the used databases and then introduce the analytical techniques and adjustments made while structuring the databases. Third, we introduce our empirical model, before discussing the weaknesses of our data. We also focus on the results of our descriptive and econometric analyses. The purpose of the descriptive analysis is to illustrate the possible correlations among the variables. In the econometric analysis, we consider whether the duration of economic crises is related to social trust and corruption. Finally, we discuss the results with respect to theoretical and practical implications, present the limitations, and offer ideas for further research.

\section{Theory and hypotheses}

Social trust is defined as the faith people put in the society to which they belong (Taylor et al., 2007). One reason for the growing interest in social trust is that it is positively correlated with many other factors in social science (Rothstein, 2005). Citizens who have high trust in their communities are also likely to have positive views of democratic institutions. They also participate more actively in politics, give more to charity and show more empathy to minorities in their societies. In addition, these people tend to be more satisfied and to have greater beliefs in their abilities to influence their own lives (Dinesen \& Thisted, 2013; Leung et al., 2011). On a societal level, countries whose citizens have high trust have better democratic institutions, possess more open economies, have higher economic growth and have less crime and corruption (Bjørnskov, 2009; Richey, 2010; Rothstein, 2013). 


\section{Creation of social trust}

The causes of social trust have long been the subject of debate among social researchers (Rothstein, 2013). Two main perspectives have a bearing on social trust. The first is the society-centred approach (Hooghe \& Stolle, 2003). Researchers who share this perspective believe that citizens of a society generate social trust through their engagement in social activities, especially volunteering. However, this approach does not align well with empirical research (Delhey \& Newton, 2003; Rothstein, 2013), which argues that there is a self-selection problem at hand, such that people who participate in voluntary associations are already high-trust citizens. In addition, voluntary activities do not contribute to the improvement of social trust among organizational members (Stolle, 2003). The second perspective holds that social trust results from the level of equality in a society (Rothstein, 2005). Equality comes in two types: economic and opportunity. Economic equality is easier to measure because it can be quantified by how resources are redistributed among members of a society. Equality of opportunity, however, is a more crucial form of equality because, even in the case of economic inequality, policies that support opportunity equality can play an important role in improving social trust. An example of this is investment in universal education programs, as education has the potential to strengthen the economic prospects and is one of the most critical factors to enhance social trust (Brehm \& Rahn, 1997). The second perspective is the institution-centred approach. Supporters of this approach believe that an honest, incorrupt and efficient government is a key factor for the development of social trust in a society (Rothstein, 2013). These supporters also believe in a strong correlation between high-trust societies and incorrupt government. Using survey data, research also concludes that honest political institutions positively contribute to interpersonal trust (Bjørnskov, 2009; Freitag \& Buhlmann, 2005). 


\section{Social trust and economics}

From an economic standpoint, social trust has a positive effect on the economy of a nation. Social trust reduces the cost of third-party interference among economic actors (Uslaner, 2002). It thus facilitates transactions while decreasing the costs of controlling, such as the costs tied to government intervention. As a result, the saved resources can be invested in other beneficial activities such as education and infrastructure to the benefit of the overall growth of the economy (Graeff \& Svendsen, 2013). In a high-trust environment, time and effort are expended more effectively because investors do not need to worry about the validity of their agents. As a result, higher productivity is likely to evolve (Knack \& Stephen, 2001). Evidence also indicates that trust affects education, rule of law and government quality. Together, these three factors increase the investment rate and provide a positive impact on economic growth (Bjørnskov, 2012). Furthermore, social trust can improve human capital, enhance government efficiency and strengthen the positive effects on economic growth (Deng et al., 2012).

\section{Corruption and its origins}

According to Søreide (2016), corruption is defined as the trade in decisions that should not be for sale. The word is associated with illegal activities that abuse authority to gain personal benefits. Corruption can also be applied to culprits who demand and facilitate trade in decisions through bribery. Consequently, corruption weakens the foundation of government authority and destroys the basis for state development. It is therefore considered a very serious form of crime.

There is no country in the world that is free of corruption. However, the problem is more severe in low-income countries than in wealthier nations (Søreide, 2016). Many researchers believe that corruption in higher-income countries or countries that have better-performing institutions may be underestimated. The reason is that in these countries, corruption happens in more subtle forms and 
usually with better concealment (Søreide, 2016). The rate of extortive corruption is often higher in poor countries, while the rate of collusive corruption is not significantly related to income levels (Søreide, 2016). Nevertheless, the types of corruption that are usually studied may not be the most dangerous ones. Cronyism, which is the connection between powerful business leaders and politicians, is usually regarded as more destructive and more difficult to measure than other forms of corruption (Lambsdorff, 2015). However, evidence suggests that poorer countries with less effective governments also suffer from cronyism (Fisman \& Miguel, 2010). Corruption on a political level is particularly detrimental to development, because politicians and business leaders exert excessive control over resources that are imperative for development (Acemoglu et al., 2001). Another example is rent-seeking. It implies improving one's share from existing resources without creating new wealth for the society. Thus, rent-seeking dwindles economic efficiency because skilled agents use their time and capability to capture the rents rather than participating in productive activities (Collier \& Goderis, 2007; Kolstad \& Wiig, 2011; Robinson et al., 2006).

\section{Social trust and corruption}

From a political standpoint, incorrupt and honest governments promote social trust inside a community, while corrupt and inefficient governments destroy trust among people (Rothstein, 2005, 2013; Sun \& Wang, 2012). By interacting with corrupt officials, citizens not only lose trust in institutions but also in other people in their communities (Rothstein, 2013; Sun \& Wang, 2012). According to Rothstein (2013), one of the reasons for this phenomenon is that it is impossible for a normal citizen to measure the trust of all the people in a society. Citizens generalize their beliefs about the trustworthiness of public officials to the whole population. If they have a negative experience with public officials, they are not likely to trust ordinary citizens. In addition, they relate to other people as being untrustworthy, because they believe others also engage in corrupt 
activities through contact with corrupt public officials. As a result, they consider themselves as corrupt individuals and thus lose trust in themselves.

Research also shows linkages between corruption and inequality that affect social trust indirectly (Uslaner, 2012). The link between equality and trust can be casually explained by two reasons (Rothstein, 2005). First, economic inequality and low equality of opportunity increase pessimism among poor people. Because they feel that societies do not treat them fairly, especially in the education and labour markets, they begin losing trust in others who possess more resources. Second, when the level of inequality is high, people do not believe that they share a common destiny. The income gap between the rich and the poor further separates the two groups, because neither group regards itself as part of a larger entity. Instead, this separation strengthens the negative stereotypes about each group, degrading the level of trust to an even lower point. It thus becomes more difficult to close the gap between the groups (Boix \& Posner, 1998).

In addition, the link among trust, corruption and inequality can be shown by distinguishing between generalized and particularized trust. Generalized trust refers to the trust in all people regardless of the differences between groups in a society. By contrast, particularized trust reflects the close relationship between similar individuals, in terms of economic situation, gender and social class. Particularized trust also implies the distrust of those outside one's own social circle (Uslaner, 2002). Corruption can only promote particularized trust. In a corrupt society, public officers only reward the people who show loyalty to them (Rothstein, 2005). Corrupt politicians also steal resources from the state to enrich themselves and their immediate business circle (Uslaner, 2012). Particularized trust is the exact opposite of social trust because it damages the relationship between people from different backgrounds (Uslaner, 2002). In a society in which people care less for those outside their own social group, social trust cannot exist. This is because 
each group only care about its own interests, at the expense of the needs of other group. Group members may even perceive demands from the other group to be in conflict with their own wellbeing, leading to more resentment and social conflict. Eventually, the rich and the poor cannot reach a common understanding and are bound to be further separated from each other. These effects create a social trap of inequality and low trust in societies that already have a high level of corruption. Therefore, corruption maintains a high level of inequality that worsen social trust in an endless and continuing cycle that seems impossible to break (Uslaner, 2012).

\section{Economic crisis duration and its consequences}

The duration of a crisis increases with the complexity of it, and complexity is related to the severity of the impact (Laeven \& Valencia, 2018). For example, longer and more complex crises are associated with larger capital outflows and worse outcomes in terms of output loss and inflation. Laeven and Valencia (2018) defined crisis duration as the start and the end of a crisis. The end date of a crisis period refers to the year before both real gross domestic product (GDP) growth and real credit growth are positive for at least two consecutive years.

Research on the financial crisis of 2007-2008 found that the crisis affected countries and individuals of different social classes unequally (Sachweh, 2018). Normally, the impact of a crisis is associated with an increase in state responsibility, greater welfare support and redistribution of wealth (Blekesaune, 2013; Naumann et al., 2016). However, this association is not homogeneous because of the differences in social class positions, national economic conditions and social spending levels (Chzhen, 2016; Mertens \& Beblo, 2016; Sachweh, 2018). On an individual level, a stronger perceived crisis impact is associated with more favourable attitudes towards welfare state support (Fraile \& Fons, 2005; Jeene et al., 2014). However, welfare state support is less 
related to a perceived crisis impact when social spending is higher, indicating that encompassing welfare states reduce the subjective impact of the crisis (Blekesaune, 2013).

Unemployment can be a 'class risk', if social consequences of economic downturns are distributed unevenly among individuals (Eurofund, 2012; Rueda, 2012; Sachweh, 2018). In general, members of disadvantaged social groups (e.g., low-income earners, low-skilled workers, young people) are exposed to greater social risks during economic downturns than members of privileged groups (Chzhen, 2016; OECD, 2019). This is because disadvantaged groups have less economic resources to buffer against economic downturns, and this is especially evident over longer periods (Kluegel, 1988). As such, they are more dependent on state benefits to maintain their standard of living than members of more privileged groups. In addition, people from disadvantaged groups often have smaller social networks that could work as additional social support during an economic crisis (Reeskens \& van Oorschot, 2014). Incidentally, during the 2007-2008 financial crisis, the increase in social spending in European countries was lowest in the countries that were most affected by the crisis. This indicates that there are differences in countries' capacities to handle the effects of economic downturns (Leschke \& Jespen, 2012). European welfare states still differ in their institutional design and generosity, as well as in their social and labour market policy responses to a crisis (Scruggs \& Allan, 2006; Starke et al., 2013; Van Hooren et al., 2014).

Hariri et al.'s (2016) study on developing countries indicates that economic shocks, such as unanticipated currency devaluations, have a strong and negative causal effect on how people rate their living conditions and sense of well-being. This research is consistent with earlier findings showing that a financial crisis adds a non-negligible cost to individual well-being and that macroeconomic movements strongly influence perceived happiness on a national basis (Di Tella et al., 2003; Montagnoli \& Moro, 2014). Furthermore, Dix-Carneiro and Kovak (2015) discovered that 
the long-term recovery of employment rates after an economic shock is fully dependent on the development of the informal sector. This suggests that informal employment keeps individuals from engaging in crime. It also indicates that labour regulations, which reduce informality and increase unemployment, can intensify the level of crime related to an economic crisis. Still, local crises that cause a reduction in labour demand may affect crime in different ways, such as by decreasing government revenues and affecting the supply of public goods (Dix-Carneiro et al., 2017).

It is hypothesized that societies with high social trust and less corruption can handle a crisis better than their counterparts. By contrast, high corruption and low social trust intensify the crisis duration. Several research findings agree that social trust plays a key role in the development of a country (Rothstein, 2005). A high level of social trust is positively correlated with stronger democratic institutions and higher economic growth and negatively correlated with the level of crime and corruption (Bjørnskov, 2009; Richey, 2010; Rothstein, 2013). Social trust is also rooted in an honest and incorrupt government (Bjørnskov, 2009; Freitag \& Buhlmann, 2005; Rothstein, 2013). For this reason, the cost of controlling economic agents is considerably lower in high-trust communities (Uslaner, 2002). Moreover, social trust reduces interference from governments and encourages business transactions. As a result, infrastructure and welfare policies benefit because governments have larger funds to invest in them (Graeff \& Svendsen, 2013). We argue that social trust can counteract the consequences of an economic crisis to a certain extent, because efficient governments can detect the errors faster and can manage challenges better. Furthermore, everyday businesses may even take advantage of the crisis to restructure their organizations, improve 
technology and develop their human resources. In addition, a low level of corruption means that public funds can be employed more optimally for the recovery of a country.

Nevertheless, a lack of trust may increase the gap between rich and poor social groups and, most importantly, promote corruption (Uslaner, 2012). Countries with a high level of corruption often ignore their potential to uplift the economy (Søreide, 2016). Evidence also shows that an economic crisis presents serious challenges to national security because it increases crime levels (DixCarneiro \& Kovak, 2015). In addition, corruption reduces a country's ability to protect its national resources, which make them more vulnerable to embezzlement (Kolstad \& Wiig, 2011). Thus, during economic crises, high corruption will increase the resentment of the poor social groups towards the elites and the governments. In addition, affected citizens may take the crisis as an opportunity to challenge the government and its management of the economy. As a result, the reduced financial budgeting during an economic crisis is further restrained to tighten security control and to protect the corrupt government from public anger and higher crime rates. These factors worsen the recovering abilities of nations and increase the duration of an economic crisis.

Hypothesis 1: Social trust has a negative correlation with the duration time of an economic crisis.

Hypothesis 2: Corruption has a positive correlation with the duration time of an economic crisis.

\section{Method}

\section{Presentation of databases}

The dataset of social trust and corruption that we applied came from the Quality of Government (QoG) Institute database (https://qog.pol.gu.se/data/datadownloads) developed by University of 
Gothenburg. The database comprises five datasets and is freely available from the QoG Institute's website. The mission of the database is to provide good governance. We exclusively worked with the QoG standard database, which is the largest dataset of the five and includes almost 2,100 variables from more than 100 data sources.

We also used the Global Crises Data by Country database. ${ }^{1}$ This database includes data related to banking, systemic malfunctioning and inflation crises measured during a period spanning from 1800 to 2016 in more than 70 countries. The Behavioral and Financial Stability (BFFS) project was founded at Harvard Business School and the Global Crises Data by Country is part of the BFFS project's database. The project maintains an ongoing real-time database of financial stability indicators and is available to both researchers and the public.

\section{Analysis techniques}

Our study is based on two methods: descriptive and econometric analysis. As a first step, we perform a descriptive analysis on a dataset including social trust, corruption and economic crisis as variables. The intention of the descriptive analysis is to glean insight into whether there are significant correlations between the duration of economic crises and social trust/corruption. As a second step, we apply econometric techniques to analyse our data. The purpose of the econometric analysis is to assess the connections between the dependent and independent variables. For the hypotheses, we introduce a multiple regression with control variables. We select the control variables to be able to exclude factors that can significantly affect the interpretation of the empirical results. In this mission, we use the software package STATA 14.0 (Wooldridge, 2016) as a basis for our analyses.

\footnotetext{
${ }^{1}$ See https://www.hbs.edu/behavioral-finance-and-financial-stability/data/Pages/global.aspx.
} 


\section{Structuring of data}

In Table 1, we compare the assortment of the original datasets with our dataset. After scaling, we kept all the countries and reduced the number of variables from 2,202 to 9. Consequently, the number of observations in our dataset is also reduced to $\sim 74 \%$ and includes 11,364 observations distributed across 211 countries. However, we collect the dataset from different public sources, and consequently, some of the variables may lack observations. Furthermore, we exclude extreme variables in the econometric analysis. Therefore, the regressions may differ in the number of observations from what we state here.

Table 1 about here

In addition, we created a dummy variable for the economic crises when at least one crisis is occurring in a specific year in a country $(1=$ at least one crisis in this year and country, $0=$ no crisis in this year and country). The reason for this is to observe the effects on the regression models when there was at least one ongoing crisis. Consequently, the number of observations in the econometric analysis is reduced to 5,112 observations (44.98\%). In the following subsections, when no specific changes are mentioned, we make no adjustments to the variables.

\section{Dependent variables}

Again, crisis duration is the period from the start to the end of a crisis. In the Global Crises Data by Country database, each crisis - whether it is related to banking, systemic malfunctioning or inflation - has a dummy variable for when a crisis is occurring in a specific year and country $(1=$ crisis, $0=$ no crisis $)$. To measure the crisis duration, we add a dummy variable for when at least 
one of the crises is occurring in a specific year in a country. Then, we count the number of consecutive crisis years to measure the duration of economic crises in each country. As a result, we measure the crisis duration in number of years between the start and the end of the crisis. The skewness of the crisis duration variable is 0.84 , which makes it acceptable for further analyses (George \& Mallery, 2011).

\section{Independent variables}

When people have social trust, they put faith in one another in a society. In the QoG standard database, social trust is reported as an index score. The index score represents an average of all country-survey scores available within each country-year observation. These scores range from 0 (lowest level of trust) to 100 (highest level of trust).

A higher level of social trust is correlated with stronger democratic institutions and higher economic growth. These factors are the foundations of economic equality (Bjørnskov, 2009; Richey, 2010). Additionally, social trust arises from economic equality, and is also a product of equality of opportunity and incorrupt governments (Rothstein, 2005). This indicates that a high level of equality in turn will increase the level of social trust or vice versa (Uslaner, 2012). Since the economic growth and equality gap of each nation are changing constantly the Social trust index should be dynamic in nature.

Corruption is defined as the abuse of public power for private gain. We use the Bayesian Corruption Index (BCI), obtained from the QoG standard database, to represent the corruption level. The BCI is a composite index of the perceived overall level of corruption and ranges between 0 (everyone agrees there is no corruption at all) and 100 (corruption is as bad as it can get). 
Studies have shown that low-income countries seem to suffer more from corruption than their wealthier counterparts (Søreide, 2016). For that reason, we believe that the severity of corruption tends to decline as nations strive to improve their economic conditions. On the other hand, it also implies that when the economic situation deteriorates, the level of corruption will increase as a result.

Additionally, corruption is regarded as one of the main obstacles for the advancement of economy and society (Søreide, 2016). As serious as it may sound, corruption hinders economic growth and social development. This is since corrupt agents abuse their political power by essentially trading public benefits for personal gains. Almost any country in the world realizes these problems and tries to eliminate or at least reduce the level of corruption. Consequently, governments keep improving policies and laws against corruption. The capability of these laws and policies depends on various factors such as the independence of courts as well as governments' transparency and institutions' effectiveness. Nevertheless, these laws and policies are bound to have some effect on corruption levels over time.

For these reasons mentioned above, it is safe for us to conclude that corruption and social trust are not static but dynamic in nature. This is important to keep in mind since neglecting the dynamic aspects in the analysis may lead to a specification error in the regressions.

\section{Control variables}

Population capabilities can affect how well the citizens of a country handle challenges and how well they are able to process news from economic crises. To measure population capabilities, we use the Human Development Index (HDI) obtained from the QoG databases. The HDI is a 
composite measure that captures the average achievements in three essential dimensions of human development: health, knowledge and standard of living.

Equality has the potential to affect the level of social trust and corruption. Higher levels of inequality may create distrust among different social classes and worsen the level of social trust. To be able to measure equality, we use the Gini index obtained from the QoG databases. The Gini index measures the degree of inequality in the distribution of family income by country. The more equal a country's income distribution, the lower is the Gini index (Gini $=0)$. The more unequal a country's income distribution is, the higher is the Gini index (Gini = 100).

\section{Results}

\section{Empirical specifications}

Interpretation of any empirical econometric analysis must be based on relevant theories to provide sound results. In this research, we use a panel data model because our dataset provides a time series for each country unit. We limit the regression analysis only to periods when at least one economic crisis is present. Consequently, we use the following empirical model only when there is an economic crisis present. We use the crisis dummy variable created previously to limit the period (see the section Structuring of data):
A: Crisis duration $_{i, t}=\alpha+\beta_{1} \times$ Social Trust $i_{, t}+\beta_{2} \times H D I_{i, t}+\beta_{3} \times$ Gini $_{i, t}+V_{t}+a_{i}+u_{i, t}$.
B: Crisis duration $n_{i, t}=\alpha+\beta_{1} \times B C I_{i, t}+\beta_{2} \times H D I_{i, t}+\beta_{3} \times$ Gini $_{i, t}+V_{t}+a_{i}+u_{i, t}$. 
In the regression model, $\alpha$ represents the intercepts of regressions, $\beta$ represents the coefficient values of each variable, $V_{t}$ represents time variance factors that do not vary between countries, $a_{i}$ represents individual-specific factors of countries that do not vary over time, and $u_{i, t}$ represents an idiosyncratic error term. The lower-case letter "i”" represents country unit, and the lower-case letter “ $\mathrm{t}$ " represents time unit (year).

We use "year" as a unit to measure the duration of an economic crises. In general, it is difficult to date some of the crises included in the dataset because of the difficulty of confirming the date of the final resolution (Reinhart \& Rogoff, 2009). The implication is that several crises risk being computed as either too short or too long.

\section{Descriptive analysis}

As Table 2 shows, social trust has a positive skewness of 0.27 ( 0.36 during economic crises), whereas corruption has a negative skewness of -0.64 ( -0.78 during economic crises). In addition, crisis duration has a positive skewness of 0.85 . The kurtosis of the three values is less than 3 . This implies that the distributions are shorter and the tails are thinner, due to less extreme values than that of a normal distribution.

Table 2 about here

Table 2 shows significant differences between how many observations are recorded in the two observed periods. In other words, we have more observations during periods of economic crises. In isolation, this implies that we have a better basis for obtaining reliable results for periods with 
an economic crisis present. However, it must be noted that the mean is an average of all countries. The standard deviation and the percentiles imply that there are large differences between countries.

Figure 1 illustrates the possible correlations among crisis duration, social trust and corruption. We observe that there is minimal correlation between social trust and the duration of economic crises. Similarly, the BCI has minimal correlation with the duration of economic crises.

Figure 1 about here

\section{Econometric analysis}

The purpose of the econometric analysis is to determine whether the indicators of economic crises are related to social trust and corruption during periods with economic crises. We used a multiple regression analysis, specifically the ordinary least squares method. In the econometric analysis, we consider only the period when it contains at least one economic crisis. We also perform a Hausman test to choose between a fixed- and random-effect estimator (Black et al., 2009). The fixed-effect row in the regression tables shows "no" for the random-effect estimator and "yes" for the fixed-effect estimator.

As Table 3 shows, the coefficient of the social trust index is statistically significant $(p<0.05$; regression number 1). Therefore, social trust reliably correlates with the duration of economic crises. This implies that with an increase of one unit in the social trust index, the duration of economic crises decreases by 0.02 year (i.e., approximately one week). This result provides support for Hypothesis 1. Table 3 also reveals that the coefficient of the BCI is not statistically 
significant. Therefore, corruption does not correlate with the duration of economic crises. Thus, Hypothesis 2 is rejected.

Table 3 about here

Fitness of the model

We report the F-test results for the fixed-effect models and the chi-square test results for the random-effect models. These results better reflect how well our regression model fits the data than a model without any independent variables. The rule of thumb is that the F-test and the chi-square test results should be less than 0.05 for us to reject the null hypothesis of the two tests (Wooldridge, 2016). The models of Hypotheses 1 have a result lower than 0.05 in the F-test and the chi-square test. Accordingly, it is safe to reject the null hypothesis.

\section{Discussion}

\section{Theoretical implications}

The econometric analysis shows that social trust is negatively correlated with the duration of economic crises. This means that higher trust reduces the duration of economic crises and lower trust increases the duration of economic crises. One week might seem much shorter than the "year" unit that measures the duration of economic crises; however, social trust is measured as an index score, which represents an average of all the surveys in a country each year. Therefore, the level 
of social trust will not drastically change from high to low within a year. By contrast, a higher level of social trust is correlated with stronger democratic institutions and higher economic growth. These factors are also the foundations of economic equality (Bjørnskov, 2009; Richey, 2010). Furthermore, social trust arises from economic equality, equality of opportunity and incorrupt governments (Rothstein, 2005). This indicates that a high level of social trust upholds a high level of equality, which in turn increases the level of social trust (Uslaner, 2012). Therefore, when there is a change in social trust, either for the better or for the worse, the direction of that change will stay the same (virtuous or vicious circle effect). This is assumed to be true even if the changes are smaller in the short run. In the long run, the changes may be greater.

Moreover, the duration of a crisis increases with the complexity of an economic crisis, and the complexity is related to the severity of the impact (Laeven \& Valencia, 2018). This indicates that social trust may marginalize the duration of economic crises by reducing their complexity and severity. Social trust can indirectly reduce the severity of the impact by facilitating investments in infrastructure and in welfare policies. Moreover, low social trust increases inequality and decreases the effectiveness of welfare programs. This usually has a negative impact on a country's recovering abilities (Soss, 2001; Tella \& MacCulloch, 2009; Uslaner, 2012).

\section{Practical implications}

Our findings indicate that social trust and corruption do not correlate during economic crises. Furthermore, our findings suggest that an increase in equality during economic crises may increase GDP growth, reduce public debt and reduce inflation rate (Nguyen \& Dinh, 2019). Therefore, equality-based policies could benefit a society in several ways during an economic crisis. In this article, we mention two of the most common policies (for further discussion about the policies, see Nguyen \& Dinh, 2019). 
Universal welfare programs reward all people equally, regardless of their social class or income, while means-tested welfare programs reward specific groups through some selection methods (Rothstein, 2005). We recommend using universal welfare programs to avoid treating disadvantaged groups differently from other groups. Means-tested programs may create resentment from unfortunate individuals towards the wealthy and decrease rather than increase social trust (Rothstein, 2005; Soss, 2001; Uslaner, 2012). Such programs will therefore likely worsen the situation, especially during downturns (Tella \& MacCulloch, 2009). By contrast, it could be difficult to gain public support to implement universal welfare programs in a society with low social trust, particularly during periods of economic constraint (Rothstein, 2005). In situations in which there is not enough public support to initiate universal welfare programs, we argue that it is better not to implement other welfare programs that may result in higher inequality.

Differences in income, early education and school quality are the key components that contribute to sustained inequality over generations (Checchi, 2001; Thomas et al., 2001). Therefore, investment in education beginning in childhood can increase productivity and reduce inequality (Heckman, 2011). Programs targeting disadvantaged children will likely generate high economic returns for those children. However, universal education programs benefit a greater number of children and generate a higher total of net positive benefits (Barnett, 2010). The benefits of investments in education, such as higher income and better health, accumulate over time (Day \& Newburger, 2002; Mirowsky \& Ross, 2005). Therefore, policy makers usually invest in policies with more short-term benefits. However, education has the potential to enhance the equality of opportunity and is one of the most critical factors to increase social trust (Brehm \& Rahn, 1997). However, during economic downturns, it seems uneconomical to invest in something that yields 
limited profit in the near future. It is therefore advisable for country states to begin with targeted programs with the goal to move to high-quality universal programs over time. Another solution is to target specific geographic areas, available for all children regardless of their social class. Targeting geographic areas reduces the cost of selection methods to identify which children are qualified for the program and potentially lessens the stigmatization of the children in the program (Checchi, 2001).

\section{Limitations}

One of the limitations of our research is the usage of secondary data. In this research, we use data from the QoG Institute database and from the BFFS project. Although these sources are trustworthy, the data might have been collected for purposes unrelated to our research. Thus, there is a possibility that this deficiency reduces the effectiveness of our empirical models. Moreover, there might be a mismatch between the two data sources. The variables included in the QoG database mostly pertain to 100 to 190 countries and territories; however, the BFFS project covers only 70 countries and territories. There are also imbalances among observations of the QoG database. Not all the variables from the QoG database contain needed information for the current research article. This irregularity, which reduces the number of observations for our research, may decrease the efficiency of the empirical interpretations (Saunders et al., 2016).

The data we use come from several countries in different periods. The applied datasets allowed us to conduct our analyses on a large number of observations. Furthermore, a large number of observations enabled us to increase the degrees of freedom and to reduce the collinearity among the explanatory variables. As a result, the efficiency of our empirical analysis is increased (http://sites.utexas.edu/sos/degreesfreedom/). We also tried to increase the internal validity of our 
research through rich data collection (Saunders et al., 2016). Moreover, we attempted to maintain a high level of external validity for our research findings. The variables we use are available in many countries, so we believe that our research findings will also apply to these (Saunders et al., 2016).

\section{Future research}

An important issue for future research is to further explore the driving capability of corruption on economic crisis duration, as it was not possible for us to establish a reliable correlation between these variables. However, it is important to note that "corruption" can be measured in many ways and also that the concept can be reframed under alternative labels (e.g., 'good governance'). Future research is thus necessary to carry out a more comprehensive analysis of the impact of corruption on economic crisis duration. Moreover, it cannot be ruled out that social trust functions as a moderator of the relationship between corruption and economic crisis duration.

Another issue that needs further investigation is the impact of an economic crisis duration of about one-two weeks on the political life of a society. This might seem to be an extremely short period, but consider, for example, the approximate cost of a worldwide crisis that lasts for this amount of time; the figure might turn out to be enormous. Econometric analyses are therefore required to shed light on this issue on a more detailed level. 


\section{References}

Acemoglu, D., Johnson, S., \& Robinson, J. A. (2001). The colonial origins of comparative development: An empirical investigation. American Economic Review, 91(5), 1369-1401.

Barnett, S. W. (2010). Universal and targeted approaches to preschool education in the United States. International Journal of Child Care and Education Policy, 4(1), 1-12. doi:https://doi.org/10.1007/2288-6729-4-1-1

Bjørnskov, C. (2009). Economic growth. In Handbook of Social Capital, 337-353.

Bjørnskov, C. (2012). How does social trust affect economic growth? Southern Economic Journal, 78(4), 1346-1368.

Black, J., Hashimzade, N., \& Myles, a. G. (2009). A dictionary of economics. Oxford: Oxford University Press.

Blekesaune, M. (2013). Economic strain and public support for redistribution: A comparative analysis of 28 European countries. Journal of Social Policy, 42(1), 57-72.

doi:10.1017/S0047279412000748

Boix, C., \& Posner, D. N. (1998). Social capital: Explaining its origins and effects on government performance. British Journal of Political Science, 28(4), 686-693.

Brehm, J., \& Rahn, W. (1997). Individual-level evidence for the causes and consequences of social capital. American Journal of Political Science, 41(3), 999-1023.

Checchi, D. (2001). Education, inequality and income inequality. LSE STICERD Research Paper No. 52. Retrieved from https://ssrn.com/abstract=1094825. 
Chzhen, Y. (2016). Perceptions of the economic crisis in Europe: Do adults in households with children feel a greater impact? Social Indicators Research, 127(1), 341-360. doi:10.1007/s11205-015-0956-Z

Collier, P., \& Goderis, B. (2007). Commodity prices, growth, and the natural resource curse: Reconciling a conundrum. CSAE working paper series. Oxford: Centre for the Study of African Economies, University of Oxford.

Day, J. C., \& Newburger, E. C. (2002). The big payoff: Educational attainment and synthetic estimates of work-life earnings. special studies. current population reports. (P23-210).

Washington, DC: Bureau of the Census (DOC), Economics and Statistics Administration.

Delhey, J., \& Newton, K. (2003). Who trusts? The origins of social trust in seven societies. European Societies, 5(2), 93-137.

Deng, W.-S., Lin, Y.-C., \& Gong, J. (2012). A smooth coefficient quantile regression approach to the social capital-economic growth nexus. Economic Modelling, 29(2), 185-197.

Di Tella, R., MacCulloch, R. J., \& Oswald, A. J. (2003). The macroeconomics of happiness. Review of Economics and Statistics, 85(4), 809-827.

Dinesen, \& Thisted, P. (2013). Where you come from or where you live? Examining the cultural and institutional explanation of generalized trust using migration as a natural experiment. European Sociological Review, 29(1), 114-128.

Dix-Carneiro, R., \& Kovak, B. K. (2015). Trade reform and regional dynamics: evidence from 25 years of Brazilian matched employer-employee data. (NBER Working Paper No. 20908). 
Cambridge: National Bureau of Economic Research. Retrieved from

https://www.nber.org/papers/w20908.pdf

Dix-Carneiro, R., Soares, R. R., \& Ulysse, G. (2017). Economic shocks and crime: Evidence from the Brazilian trade liberalization. (NBER Working Paper No. 23400). Cambridge: National Bureau of Economic Research. Retrieved from https://www.nber.org/papers/w23400.pdf

Eurofund. (2012). Third European Quality of Life Survey: Quality of life in Europe: Impacts of the crisis. Luxembourg: Publications Office of the European Union. doi:10.2806/42471

Fisman, R., \& Miguel, E. (2010). Economic gangsters: Corruption, violence, and the poverty of nations. Princeton, NJ: Princeton University Press.

Fougère, D., Kramarz, F., \& Pouget, J. (2010). Youth unemployment and crime in France. Journal of the European Economic Association, 7(5), 909-938. doi:10.1162/JEEA.2009.7.5.909

Fraile, M., \& Fons, M. F. (2005). Explaining the determinants of public support for cuts in unemployment benefits spending across OECD Countries. International Sociology, 20(4), 459481. doi: $10.1177 / 0268580905058327$

Freitag, M., \& Buhlmann, M. (2005). Political institutions and the formation of social trust: An international comparison. Politische Vierteljahresschrift, 46(4), 575-586.

George, D., \& Mallery, P. (2011). SPSS for Windows step by step: A simple guide and reference 18.0 update. Boston: Pearson Education.

Graeff, P., \& Svendsen, G. T. (2013). Trust and corruption: The influence of positive and negative social capital on the economic development in the European Union. Quality \& Quantity: International Journal of Methodology, 47(5), 2829-2846. 
Hariri, J. G., Bjørnskov, C., \& Justesen, M. K. (2016). Economic shocks and subjective wellbeing: Evidence from a quasi-experiment. The World Bank Economic Review, 30(1), 55-77. doi:https://doi.org/10.1093/wber/lhv004

Heckman, J. J. (2011). The economics of inequality: The value of early childhood education. American Educator, 35(1), 31-35.

Hooghe, M., \& Stolle, D. (2003). Generating social capital: Civil society and institutions in a comparative perspective. New York: Palgrave/Macmillan.

Jeene, M., van Oorschot, W., \& Uunk, W. (2014). The dynamics of welfare opinions in changing economic, institutional and political contexts: An empirical analysis of Dutch deservingness opinions, 1975-2006. Social Indicators Research, 115(2), 731-749. doi:https://doi.org/10.1007/s11205-012-0230-6

Jorgenson, D. (1991). Productivity and economic growth. In R. Ernst, \& J. Triplett (Eds.), Fifty years of economic measurement: The jubilee of the conference on research in income and wealth (pp. 19-118). Chicago: University of Chicago Press.

Kluegel, J. R. (1988). Economic problems and socioeconomic beliefs and attitudes. Research in Social Stratification and Mobility, 7, 273-302.

Knack, P. J., \& Stephen, Z. (2001). Trust and growth. The Economic Journal, 111(470), 295-321.

Kolstad, I., \& Wiig, A. (2011). Natural resources, corruption and trust: A complex relationship. Chr. Michelsen Institute. Retrieved from https://www.cmi.no/publications/4316-naturalresources-corruption-and-trust 
Laeven, L., \& Valencia, F. (2018). Systemic banking crises revisited. (IMF Working Paper No. 18/206). Washington, DC: International Monetary Fund.

Lambsdorff, J. G. (2015). Preventing corruption by promoting trust - Insights from behavioral science. Passauer Diskussionspapiere, Volkswirtschaftliche Reihe, 69(15).

Leschke, J., \& Jepsen, M. (2012). Introduction: Crisis, policy responses and widening inequalities in the EU. International Labour Review, 151(4), 289-312. doi:10.1111/j.1564913X.2012.00150.X

Leung, Ambrose, Kier, C., Fung, T., Fung, L., \& Sproule, R. (2011). Searching for happiness: The importance of social capital. Journal of Happiness Studies, 12(3), 443-462.

Lin, M.-J. (2008). Does unemployment increase crime? Evidence from U.S. data 1974-2000. Journal of Human Resources, 43(2), 413-436.

Mertens, A., \& Beblo, M. (2016). Self-reported satisfaction and the economic crisis of 20072010: Or how people in the UK and Germany perceive a severe cyclical downturn. Social Indicators Research, 125(2), 537-565. doi:https://doi.org/10.1007/s11205-014-0854-9

Mirowsky, J., \& Ross, C. E. (2005). Education, cumulative advantage, and health. Ageing International, 30(1), 27-62. doi:10.1007/BF02681006

Montagnoli, A., \& Moro, M. (2014). Everybody hurts: Banking crises and individual wellbeing. (SERPS no. 2014010). Sheffield: Department of Economics, University of Sheffield.

Naumann, E., Buss, C., \& Bähr, J. (2016). How unemployment experience affects support for the welfare state: A real panel approach. European Sociological Review, 32(1), 81-92. doi:10.1093/esr/jcv094 
Nguyen, J., \& Dinh, T. (2019). Towards a model of economic crisis, social trust \& corruption. Bergen: Norwegian School of Economics.

OECD. (2019). Society at a glance 2019: OECD social indicators. Paris: OECD Publishing. doi:https://doi.org/10.1787/soc_glance-2019-en

Ostrom, E., \& Ahn, T. (2009). The meaning of social capital and its link to collective action. In G. Svendsen, \& G. Svendsen (Eds.), Handbook of social capital. The troika of sociology, political science and economics (pp. 17-35). Cheltenham: Edward Elgar.

Raphael, S., \& Winter-Ebmer, R. (2001). Identifying the effect of unemployment on crime. Journal of Law and Economics, 44(1), 259-283. doi:https://doi.org/10.1086/320275

Reeskens, T., \& van Oorschot, W. (2014). European feelings of deprivation amidst the financial crisis: Effects of welfare state effort and informal social relations. Acta Sociologica, 57(3), 191206. doi:https://doi.org/10.1177/0001699313504231

Reinhart, C. M., \& Rogoff, K. S. (2009). This time is different: Eight centuries of financial folly. Princeton, NJ: Princeton University Press.

Richey, S. (2010). The impact of corruption on social trust. American Politics Research, 38(4), 676-690.

Robinson, J., Torvik, R., \& Verdier, T. (2006). The Political foundations of the resource curse. Journal of Development Economics, 79, 447-468.

Rothstein, B. (2005). All for all: Equality, corruption, and social trust. World Politics, 58, 41-72. 
Rothstein, B. (2013). Corruption and social trust: Why the fish rots from the head down. Social Research, 80(4), 1009-1032.

Rueda, D. (2012). West European welfare states in times of crisis. In N. G. Bermeo, \& J. Pontusson (Eds.), Coping with crisis: Government reactions to the great recession (pp. 361-409). New York: Russell Sage Foundation.

Sachweh, P. (2018). Conditional solidarity: Social class, experiences of the economic crisis, and welfare attitudes in Europe. Social Indicators Research, 139(1), 47-76.

doi:https://doi.org/10.1007/s11205-017-1705-2

Saunders, M., Lewis, P., \& Thornhill, A. (2016). Research methods for business students. Harlow: Pearson.

Scruggs, L., \& Allan, J. P. (2006). Welfare state decommodification in 18 OECD countries: A replication and revision. Journal of European Social Policy, 16(1), 55-72. doi:https://doi.org/10.1177/0958928706059833

Soss, J. (2001). Unwanted claims: The politics of participation in the U.S. welfare system. Social Service Review, 75(4), 691-693.

Starke, P., Kaasch, A., \& van Hooren, F. (2013). The welfare state as crisis manager: Explaining the diversity of policy responses to economic crisis. London: Palgrave Macmillan.

Stolle, D. (2003). Generating social capital: Civil society and institutions in a comparative perspective. New York: Palgrave/Macmillan.

Sun, W., \& Wang, X. (2012). Do government actions affect social trust? Cross-city evidence in China. Social Science Journal, 49, 447-457. 
Søreide, T. (2016). Corruption and criminal justice: Bridging economic and legal perspectives. Cheltenham: Edward Elgar.

Taylor, P., Funk, C., \& Clark, A. (2007). Americans and social trust: Who, where and why. Retrieved from http://www.pewresearch.org/wp-content/uploads/sites/3/2010/10/SocialTrust.pdf

Tella, R. D., \& MacCulloch, R. (2009). Why doesn't capitalism flow to poor countries? Brookings Papers on Economic Activity, 40(1), 285-332.

Thomas, V., Wang, Y., \& Fan, X. (2001). Measuring education inequality: Gini coefficients of education (English). (Policy, Research working paper no. WPS 2525). Washington, DC: World Bank. Retrieved from http://documents.worldbank.org/curated/en/361761468761690314/Measuring-educationinequality-Gini-coefficients-of-education

Uslaner, E. (2002). The moral foundations of trust. New York: Cambridge University Press.

Uslaner, E. (2012). Trust and corruption revisited: how and why trust and corruption shape each other. Quality \& Quantity, 47(6), 3603-3608.

van Hooren, F., Starke, P., \& Kaasch, A. (2014). The shock routine: economic crisis and the nature of social policy responses. Journal of European Public Policy, 21(4), 605-623. doi:10.1080/13501763.2014.887757

Wooldridge, J. M. (2016). Introductory econometrics: A Modern Approach. Mason, OH: Cengage Learning. 
Wu, X., Perloff, J. M., \& Golan, A. (2002). Effects of government policies on income distribution and welfare. (IRLE working paper \#86-02). Berkeley: University of California Berkeley, Institute for Research on Labor and Employment. 
Table 1. Downscaling of the dataset.

\begin{tabular}{lccc}
\hline & $\begin{array}{c}\text { Number of countries } \\
\text { and territories }\end{array}$ & $\begin{array}{c}\text { Number of } \\
\text { observations }\end{array}$ & $\begin{array}{c}\text { Number of } \\
\text { variables }\end{array}$ \\
\hline Original datasets & 211 & 15403 & 2202 \\
Our dataset & 211 & 11364 & 9 \\
Percentage & $100 \%$ & $73,78 \%$ & $0,41 \%$ \\
\hline
\end{tabular}


Table 2. Descriptive statistics for corruption and social trust from the entire sample (descriptive statistics about crisis duration are when a crisis is present).

\begin{tabular}{lccc}
\hline Statistic & Social trust & Corruption & Crisis duration \\
\hline Dbs & 1168 & 5639 & 1103 \\
Crisis & 873 & 4310 & 1103 \\
Non-crisis & 295 & 1329 & - \\
Mean & 35,69 & 47,17 & 9,71 \\
Median & 35,75 & 51,14 & 7 \\
Std. Dev & 17,03 & 15,80 & 7,39 \\
Skewness & 0,27 & $-0,64$ & 0,85 \\
Kurtosis & 2,45 & 2,45 & 2,55 \\
Percentiles: & & & \\
1 & 4,68 & 10,35 & 1 \\
50 & 35,75 & 51,14 & 7 \\
99 & 71,12 & 72,62 & 27 \\
\hline
\end{tabular}


Table 3. Regression table for duration of economic crisis and social trust (1) and duration of economic crises and corruption (2).

\begin{tabular}{lcc}
\hline & $\begin{array}{c}(1) \\
\text { Crisis duration }\end{array}$ & $\begin{array}{c}(2) \\
\text { Crisis duration }\end{array}$ \\
\hline Social trust index & $-0,0192^{*}$ & \\
& $(-2,55)$ & \\
HDI & $7,201^{* *}$ & $-5,045^{*}$ \\
& $(2,87)$ & $(-2,55)$ \\
Gini & 0,0218 & \\
& $(1,04)$ & 0,00245 \\
Bayesian corruption index & & $(0,17)$ \\
& & $-0,0100$ \\
cons & & $(-0,41)$ \\
& 0,703 & $10,52^{* * *}$ \\
\hline & $(0,27)$ & $(5,04)$ \\
$\mathrm{R}^{2}$ within & 28 & 81 \\
$\mathrm{R}^{2}$ overall & 0,593 & 0,116 \\
$\mathrm{R}^{2}$ between & 0,00156 & 0,000247 \\
Fixed effect & 0,00697 & 0,0114 \\
Prob $>$ F & No & No \\
Prob $>$ chi ${ }^{2}$ & & \\
\hline
\end{tabular}

$t$ statistics are in parentheses.

${ }^{*} p<0.05,{ }^{* *} p<0.01,{ }^{* * *} p<0.001$ 
Figure 1. Social trust and degree of corruption related to crisis duration.
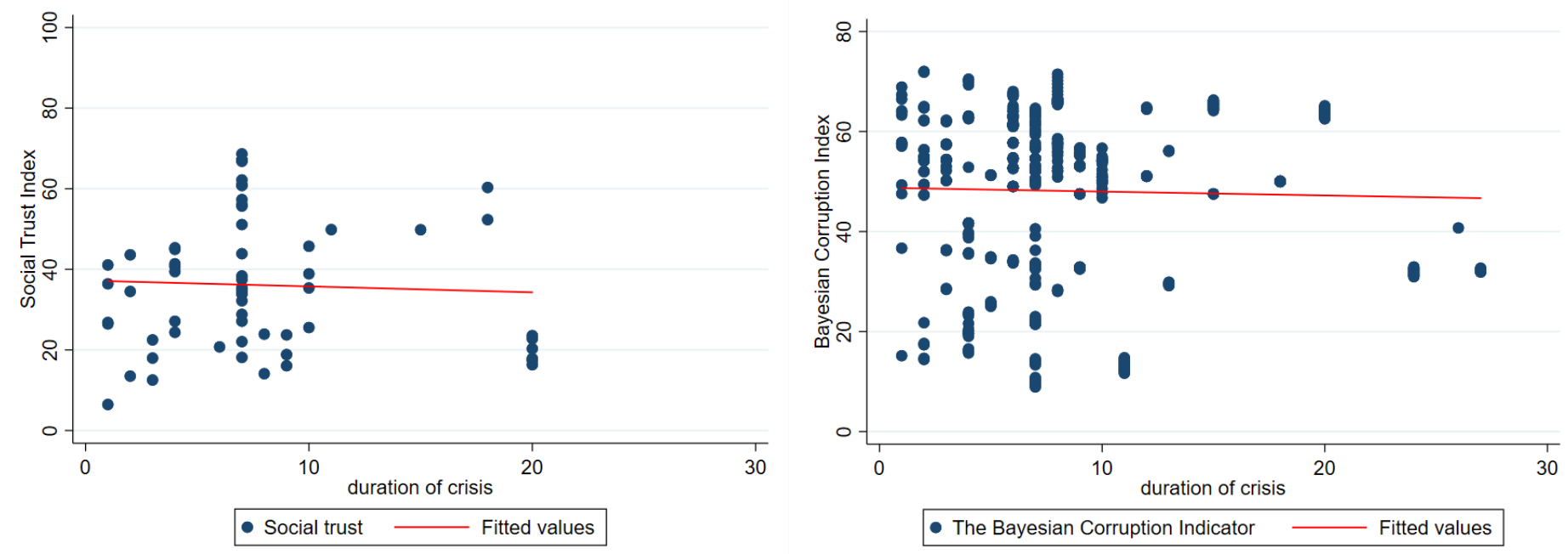